\title{
The presence of ovarian cysts in a captive Antillean manatee (Trichechus manatus manatus L. 1758)
}

\author{
Karolina Goździewska-Harłajczuk ${ }^{1 *}$ D, Joanna Klećkowska-Nawrot ${ }^{1}$ and Stanisław Dzimira ${ }^{2}$
}

\begin{abstract}
Background: Several pathological changes associated with reproductive systems of marine mammals have been reported in primary literature. However, no such records exist regarding ovarian cysts in the Antillean manatee (Trichechus manatus manatus L. 1758).

Case presentation: A nulliparous female Antillean manatee, held in captivity at the Wroclaw Zoological Garden, died in April 2015. The animal was $370 \mathrm{~cm}$ long from nose to tail and weighed $670 \mathrm{~kg}$. The width of manatee's fluke was $80 \mathrm{~cm}$. The post-mortem examination of the reproductive system showed the numerous pathological cysts on the external surface of the left and the right ovaries. Morphologically, the cysts had varying diameters and were attached to the ovaries by stalks. Some of the cysts were thin-walled and contained fluid, while several others were solid or contained a semi-solid mass. The structure of the ovaries displayed features of the polycystic ovary syndrome (PCOS). The cysts also exhibited positivity with cytokeratin and vimentin. There were no pathological changes within the uterus, uterine tube and vagina.
\end{abstract}

Conclusion: Although we were unable to definitively determine the exact source of the ovarian cysts in the studied manatee, we found that one of the causes may be age-related. Our study also revealed that ovarian cysts in the Antillean manatee form both types of corpora lutea (CL).

Keywords: Case history, Ovarian cysts, Antillean manatee, Trichechus manatus manatus

\section{Background}

The West Indian manatee (Trichechus manatus L. 1758), also known as the "sea cow," the American manatee or lamantine, can be divided into two subspecies: the Florida manatee (Trichechus manatus latirostris) and the Antillean or Caribbean manatee (Trichechus manatus manatus) [1-5]. According to the classification of the International Union for Conservation of Nature (IUCN, 2008) Red List of Threatened Species, the Antillean manatee is an endangered species [6]. The manatee is also legally protected under the Marine Mammal Protection Act [7]. The Antillean manatees live in freshwater as well as brackish and salty water off the Caribbean coast, off the coast of French Guiana and the Orinoko

\footnotetext{
* Correspondence: k.gozdziewska.wroc@gmail.com

${ }^{1}$ Department of Animal Physiology and Biostructure, Faculty of Veterinary

Medicine, Wroclaw University of Environmental and Life Sciences,

Kozuchowska 1/3, 51-631 Wroclaw, Poland

Full list of author information is available at the end of the article
}

river [8-11]. The Sirenian reproductive cycle has been widely studied in the Florida manatee [12-15]. Their reproductive activity is seasonal [12]. The length of the reproductive cycle of the manatee may be influenced by environmental factors, such as the water temperature, type of feed and individual characteristics [12-16]. Studies of the Antillean manatees that inhabit fresh water suggest that the availability of vegetation in the high water period and the presence of deep-water areas in the dry period strongly affect their choice of habitat [9]. However, it is still unclear which factors regulate the reproduction cycle in this subspecies of manatee [9]. Moreover, there may be differences in the seasonal reproductive activity between captive and wild manatees $[12,13,17]$. Based on the studies of the Florida manatee, manatees have been classified as polyovular, indicating that several large corpora lutea $(\mathrm{CL})$ are present in its ovaries [18, 19]. Nulliparous sexually mature Florida manatees have an irregular ovarian surface, and there 
are several Graffian cells (GC) as well as CL or corpora albicantia (CA) present in their ovaries, which suggests that manatees may have a number of oestrus cycles prior to conception $[12,18]$. The ovaries in immature (newborn) Amazonian manatees (Trichechus inunguis) have a smooth surface without follicles [20]. On the other hand, in the ovulating mature females, they have an irregular surface with numerous GF, located especially in the ovarian cranial pole that have a diameter up to $8.6 \mathrm{~mm}$ [20]. In the Amazonian manatee ovaries ruptured follicles (CA) and unruptured follicles (corpora atretica CAt) were recognized in addition to follicles undergoing atresia [20]. There are two types of CL present in the manatee: $\mathrm{CL}$, one of which results from luteinization of an unruptured follicle, and one which forms from an ovulated follicle [20]. CL develop as a result of luteinization of the remaining granulosa and theca cells. The diameter of multiple $\mathrm{CL}$ on the ovaries of the Florida manatee ranges from 4.8 to $7.6 \mathrm{~mm} \mathrm{[18]} \mathrm{or} 2$ to $9.5 \mathrm{~mm}$ [19], while the GF may be two times larger than the CL. The length of the oestrus cycle of the Florida manatee varies from 28 to 42 days [13]. Studies of the CL in mammals revealed the presence of two types of steroidogenic cells: the granular lutein cells (GLC) and the theca lutein cells (TLC) $[19,21]$, which was confirmed in the CL of the Florida manatee [19]. The correct development of individual ovarian follicles is regulated by endocrine, paracrine and autocrin mechanisms [22]. In mammals, the transforming growth factor $\beta$ (TGF $\beta$ ), which can occur as the TGF $\beta_{1}$ and TGF $\beta_{2}$ subtype, is one of the main intrafollicular regulator proteins [22-24]. A previous study in porcine ovaries showed that TGF $\beta_{1}$, produced by theca cells, affected the growth and differentiation of follicle cells, as well as the stromal reorganization in follicles [22]. Dysfunction of the control of the follicular development may lead to the formation of abnormal follicles (with active secretory activity), which, in effect, may cause dysregulation of the entire reproductive cycle and infertility.

Ovarian cysts are a disorder of the ovaries. They may be functional or pathologic. They can be divided into three groups: follicular cysts (single, multiple, unilateral, bilateral), luteal cysts and CL cysts [35]. Follicular cysts form from follicles, which are not released during ovulation and continue to grow, while luteal cysts form from follicles after ovulation [25]. Follicular cysts contain granular cells, including fragments of the cumulus oophorus. They are thin-walled and filled with fluid. Luteal cysts are derived from follicular cysts whose walls have undergone luteinisation. They are firm and contain a thick wall. CL cysts are a type of functional ovarian cyst and develop from the CL, which does not regress and enlarges after ovulation. Several forms of ovarian cyst may be distinguished based on another classification, including simple serous, endometrial (occurring in the course of endometriosis), dermoid, mucus-filled cysts and cysts containing a solid mass [26]. Ovarian cysts may be benign (resulting from an unruptured follicle), but they may also form a malignant lesion, such as the cystadenoma or cystadenocarcinoma [27-29].

Studies on ovarian cysts are most commonly reported in humans [30, 31], cattle [32-34], pigs [35], horses [36], goats [37], sheep [38], dogs [39, 40], cats [41], guinea pigs [42, 43], mice [44, 45] and rhesus monkeys [46]. There have also been several reports of ovarian cysts in marine mammals, such as dugongs [47] and dolphins [48]. An ovarian tumour and uterine tumour (leiomyoma and carcinoma) were described in a Florida manatee (Trichechus latistrosis) [49]. Additionally, an ovarian neoplasm was recognized in the Southern Elephant seal (Mirounga leonina) [50], and uterine tumour was found in a grey seal (Halichoerus grypus) [51, 52].

To the authors' knowledge, there exists no description of ovarian cysts in the Antillean manatee in literature. Hence, the aim of this study was the description of a case of ovarian cysts observed during necropsy in an Antillean manatee. This examination could be of interest to those studying marine mammals as well as husbandry specialists and clinicians.

\section{Case presentation}

A nulliparous female Antillean manatee was imported from the Tierpark in Berlin (Germany) to the Wroclaw Zoological Garden (Poland) at the end of 2014 year. The animal was 23 years old (born on November 4, 1992 in Nuremberg). Following its arrival at the Wroclaw Zoo, the animal was apathetic, had poor appetite, varying breath amplitudes and an improper posture in water (the animal assumed a vertical position and drifted in the water). Furthermore, it avoided the animal care personnel. According to the information from the Tierpark, the animal had no disease symptoms and did not receive any medication. The animal did not undergo any treatment in the Wroclaw Zoo and died on April 4, 2015. A post-mortem study was performed several hours after the animal's death. The left and right ovaries, as well as the uterine tube, uterus and vagina, were collected for analysis. Morphological, histopathological and immunohistochemical examinations were performed (Additional file 1). The entire reproductive tract (uterus, uterine tube, ovaries, vagina and broad ligaments ligamentum latum uteri) weighed approximately $8 \mathrm{~kg}$, and was $55.4 \mathrm{~cm}$ long. The vagina measured $15.4 \mathrm{~cm}$ from the cervix to the hymen, and had an internal circumference of $6 \mathrm{~cm}$ (Fig. 1). The ovarian bursa ovarica enclosed each ovary (Fig. 1a-b). The right ovary (together with the ovarian bursa) was $23 \mathrm{~cm}$ wide, $24 \mathrm{~cm}$ long, $15 \mathrm{~cm}$ thick, and weighed $1.8 \mathrm{~kg}$. It contained multiple cysts, which were located on the ovarian 


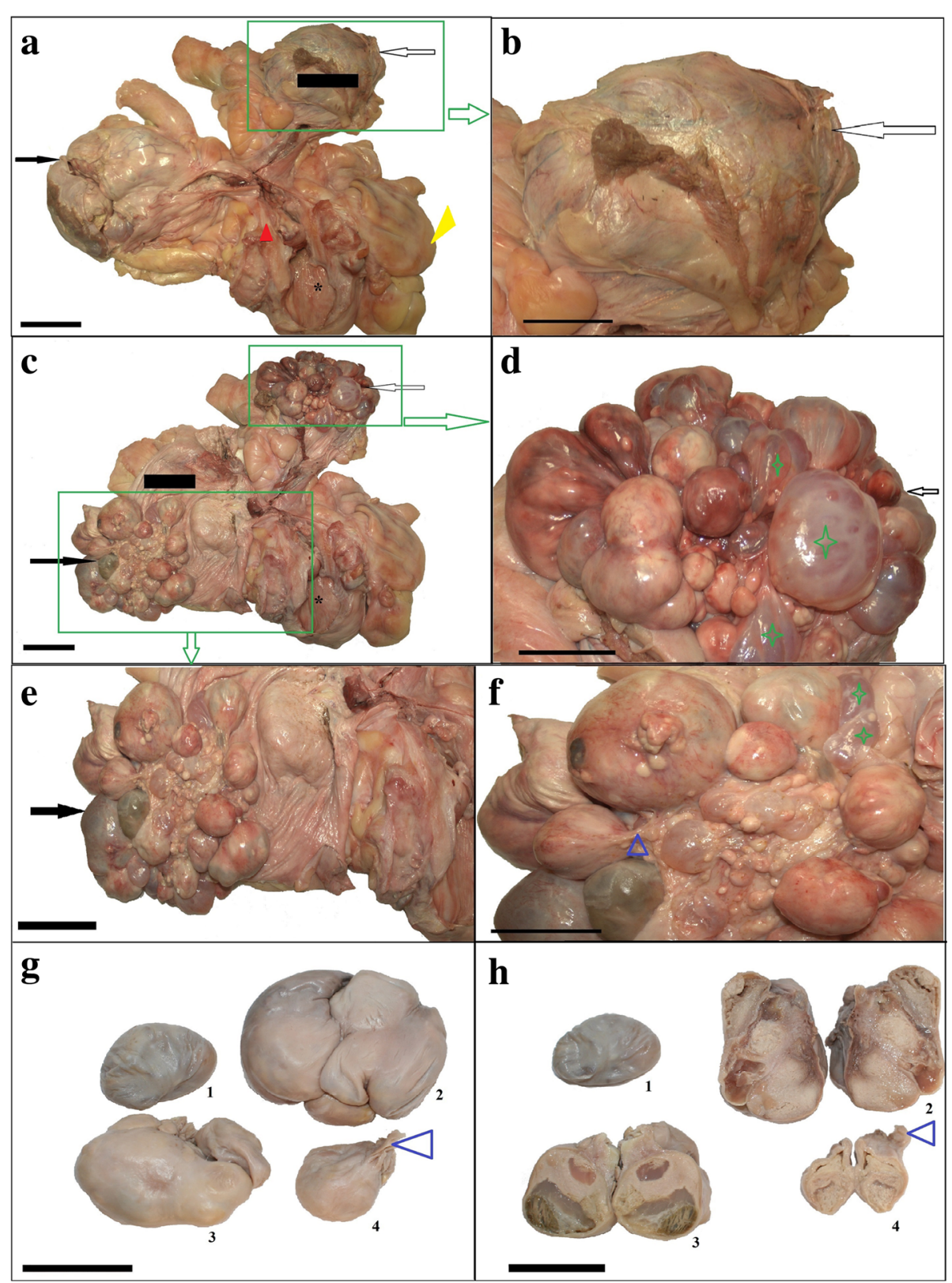

Fig. 1 Appearance of the female reproductive organs in the Antillean manatee examined in this study. a right ovary (black arrow) and left ovary (white arrow) with bursa ovarica (black line), uterine tube, uterus (red arrow), vagina (black asterisk) and ligamentum latum uteri (yellow arrow). Scale bar $=10 \mathrm{~cm}$. b Left ovary (white arrow). Scale bar $=5 \mathrm{~cm}$. $\mathbf{c}$ Right and left ovaries without bursa ovarica. Scale bar $=10 \mathrm{~cm}$. d Many ovarian cysts within left ovary. Cysts with fluid (green asterisks). Scale bar $=5 \mathrm{~cm}$. e Right ovary. Scale bar $=10 \mathrm{~cm}$. f The right ovary with many ovarian cysts magnification of e picture. Cysts with fluid (green asterisks), stalk (blue arrow). Scale bar $=5 \mathrm{~cm} \mathbf{g}$ Four (1-4) ovarian cysts with different irregular shape. Stalk (blue arrow). Scale bar $=5 \mathrm{~cm}$. h Cross section of ovarian cysts. 1- cyst with thin wall layer and with fluid inside, 2, 3, 4- cysts with shapeless masses and with small area of fluid or gelatinous substance. Stalk (blue arrow). Scale bar $=5 \mathrm{~cm}$

surface (Fig. 1c-f). The cysts (10 of which were selected for analysis based on the size) were $65.8 \pm 25.6 \mathrm{~mm}$ in diameter and were predominantly oval in shape (Fig. 1e-f). Some of them were also irregular. Most of the cysts were attached to the ovary by stalks (Fig. 1f). Some of the cysts were fluid-filled sacs surround by a thin wall, while several cysts appeared as hard, solid masses. In some cysts, there were semi-solid accumulations (Fig. 1g, h). The left ovary (together with the ovarian bursa) was approximately $19 \mathrm{~cm}$ wide, $17 \mathrm{~cm}$ long, $14 \mathrm{~cm}$ thick and weighed $1.4 \mathrm{~kg}$. That ovary was similar in appearance to the right ovary. The fluid-filled cysts (10 selected larger cysts) were $63.8 \pm 24.2 \mathrm{~mm}$ in diameter and were of different shapes (Fig. 1c-d). Cystic cavities were present in both 
the right and the left ovaries (Fig. 1c-d). Additionally, the surface lining showed evidence of hematoma around the edge of the cysts, mainly in the left ovary (Fig. 1d) in comparison to the right ovary (Fig. 1f). The microscopic examination revealed the presence of a poorly differentiated epithelium and mucosa of the uterus and uterine tube, suggesting autolytic changes (Fig. 2a-c and e-f). An abundant layer of smooth muscle and connective tissue was detected in specimens from the wall of the uterus and cervix (Fig. 2a-d). In some segments of the cervix, there was a predominance of connective tissue and collagen fibres over smooth muscle cells (Fig. 2c).

Due to the physiological presence of two types of CL in the manatee ovaries, we were able to distinguish type I CL cysts (formed from the CL and caused by the lack of ovulation in the GF) and type II CL cysts (formed from the CL following ovulation in the GF). Small and large ovarian cysts, surrounded by a connective tissue capsule, were found in specimens from the ovarian follicles (Fig. 3). The connective tissue formed septi that extended from the tissue wall into the cyst (Figs. 3e and 5c). There were also structures lined with high columnar epithelium containing a weakly positive eosin fluid (Fig. 3a-b). Next to those structures, we found cysts containing a darker, denser mass lined with a thin flattened epithelium (Fig. 3c-d) or peripheral cells with foamy cytoplasm. Some cysts contained a dark pink, uniform mass (Fig. 3c-d). The most common cysts were lined with connective tissue of varying thickness containing an eosinophilic cytoplasm and a dark blue nucleus (Fig. 3a-d). We also found different kinds of macroscopically visible cysts, which contained numerous cells. There were no amorphous masses with fibrous connective tissue (Figs. 3e, f, and 4c, d). Some of the cystic cavities were divided into two or more sacs (Figs. $3 \mathrm{a}$ and $4 \mathrm{a}$ ). Numerous lymphocytes were found within the connective tissue of the cyst capsules (Figs. 3c and 4b). Smooth muscle cells were visible within the wall of the cysts (Fig. 4b). Numerous fibroblasts with elongated nuclei

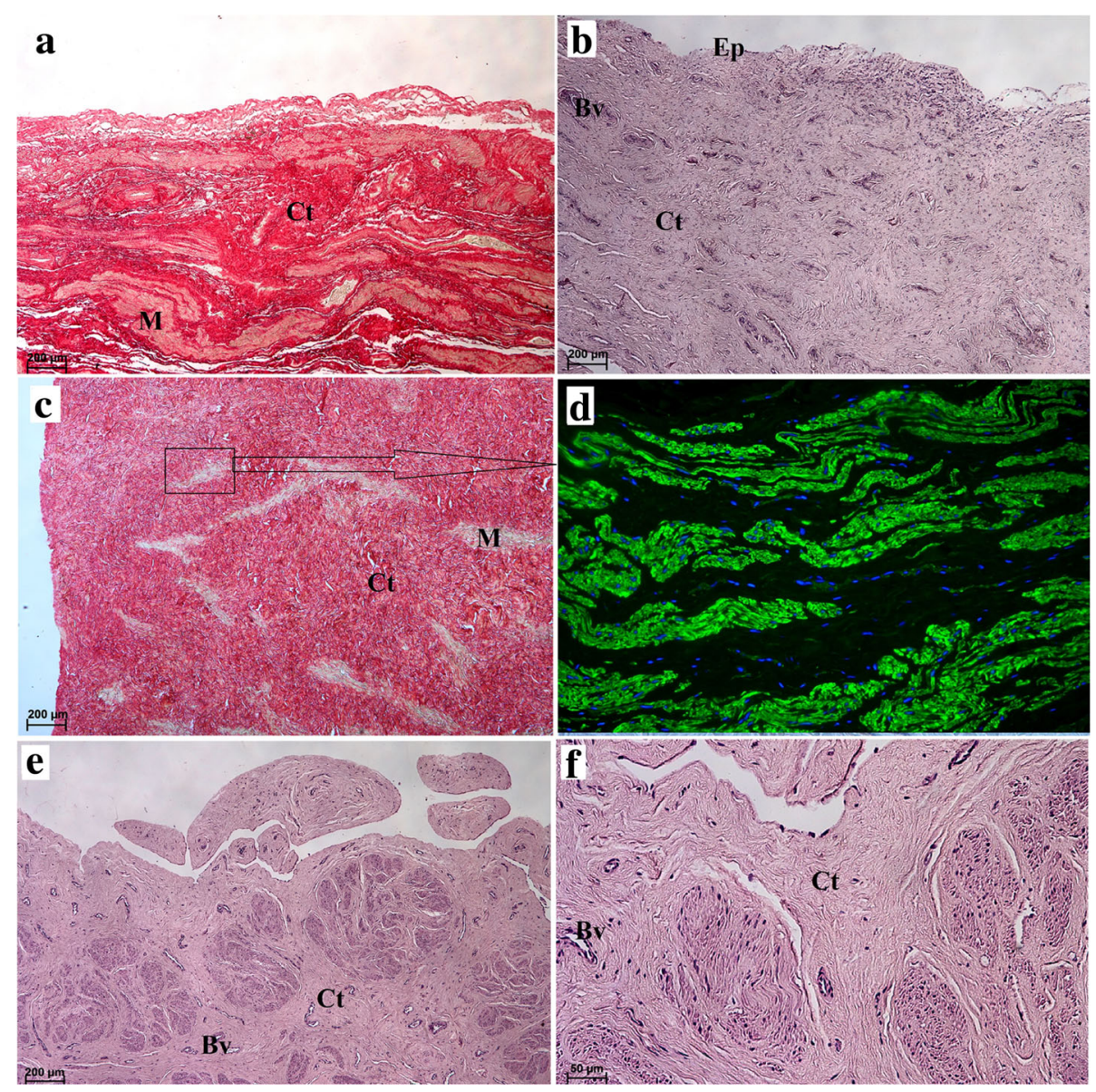

Fig. 2 Microscopic structure of the uterus and the uterine tube in the Antillean manatee examined in this study. a Picrosirius red staining. Scale bar $=200 \mu \mathrm{m}$. b H\&E staining. Scale bar $=200 \mu \mathrm{m}$. c Picrosirius red staining. Scale bar $=200 \mu \mathrm{m}$. $\mathbf{d}$ a-actin positive expression. e-f Uterine tube. H\&E staining. Scale bar $=200 \mu \mathrm{m}$ and $50 \mu \mathrm{m}$. Abbreviations: Ct: connective tissue; Ep: epithelium; M: muscle; Ac: a actin; Bv: blood vessel 


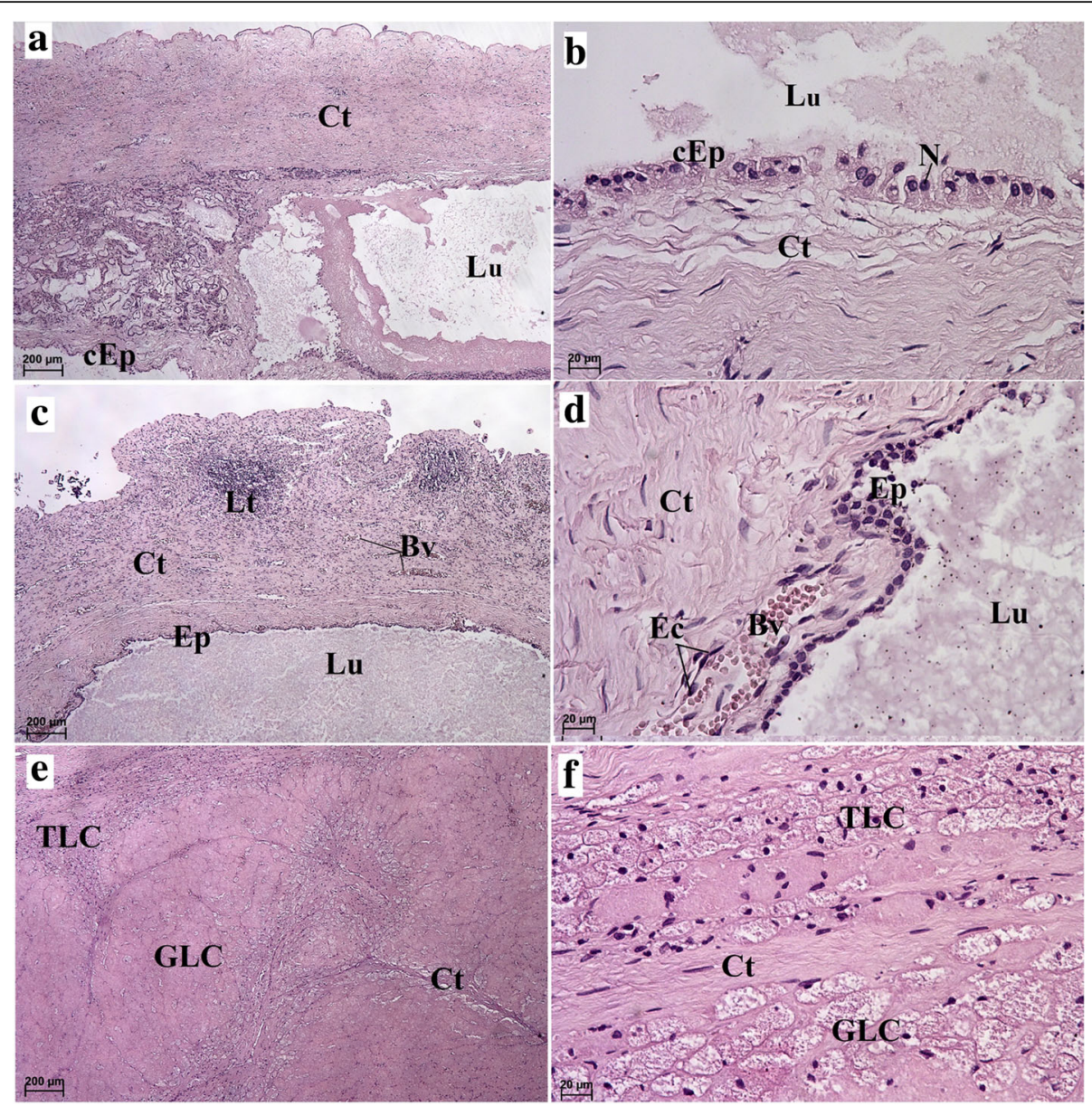

Fig. 3 Microscopic appearance of the type of ovarian cysts (I type of CL cysts) in the Antillean manatee examined in this study. a H\&E staining. Scale bar $=200 \mu \mathrm{m}$. b H\&E staining. Scale bar $=20 \mu \mathrm{m}$. c H\&E staining. Scale bar: $200 \mu \mathrm{m}$. d H\&E staining. Scale bar $=20 \mu \mathrm{m}$. e H\&E staining. Scale bar $=200 \mu \mathrm{m}$. f H\&E staining. Scale bar $=20 \mu \mathrm{m}$. Abbreviations: Ct: connective tissue; Ec: endothelial cells; Ep: epithelium; CEp: columnar epithelium; Lu: lumen; GLC: granular lutein cells; TLC: theca lutein cells; Bv: blood vessel; N: nucleus

were visible within the connective tissue of the cysts. (Fig. 3b-f). The fluid that filled some of the cysts stained weakly with hematoxylin and eosin (H\&E) or Masson-Goldner trichrome staining. The cystic blood vessels were lined with visibly flattened endothelial cells (Figs. 3d and $4 \mathrm{~d}$ ). The TLC were approximately half the size of the GLC (Figs. 3f and 4d). The TLC and GLC nuclei were oval and were located peripherally (Figs. 3 f and $4 c, d$ ).

The histological examination of the follicular stalk wall revealed that it had a papillary structure and contained a simple columnar epithelium. However, periodic acidSchiff (PAS) staining did not show the presence of glycans, glycoconjugates and neutral glycoproteins within the epithelial cells of these papillary structures (Fig. 6a, e). On the other hand, alcian blue $\mathrm{pH} 2.5(\mathrm{AB} \mathrm{pH} 2.5)$ staining revealed the presence of a small amount of mucins within these papillary structure (Fig. 6f). Immunohistochemistry showed that the epithelia of the cysts expressed cytokeratin (Figs. 6b-c). In the Antillean manatee, vimentin was strongly expressed by the stromal cells of the connective tissue and in ovarian TLCs and GLCs (Figs. 5 and $6 \mathrm{~d}$ ), but it was not found within the epithelium.

\section{Discussion and Conclusion}

Ovarian cysts diagnosed in humans and some animal species can be divided into physiological cysts (functional ovarian cysts) and pathological benign cysts [30-33]. Sometimes, they can transform into neoplastic tumours, such as an ovarian serous or an ovarian mucous cystadenoma or malignant tumours such as mucinous, serous or papillary cystadenocarcinoma $[53,54]$, as well as teratoma [55]. Neoplastic ovarian cysts can be life-threatening. In our study, the pathological changes in the Antillean manatee ovaries proved to be cysts, previously described in other animal species [47, 48]. This is contrary to the findings of the study on the female Florida manatee (Trichechus manatus latistrosis), where 


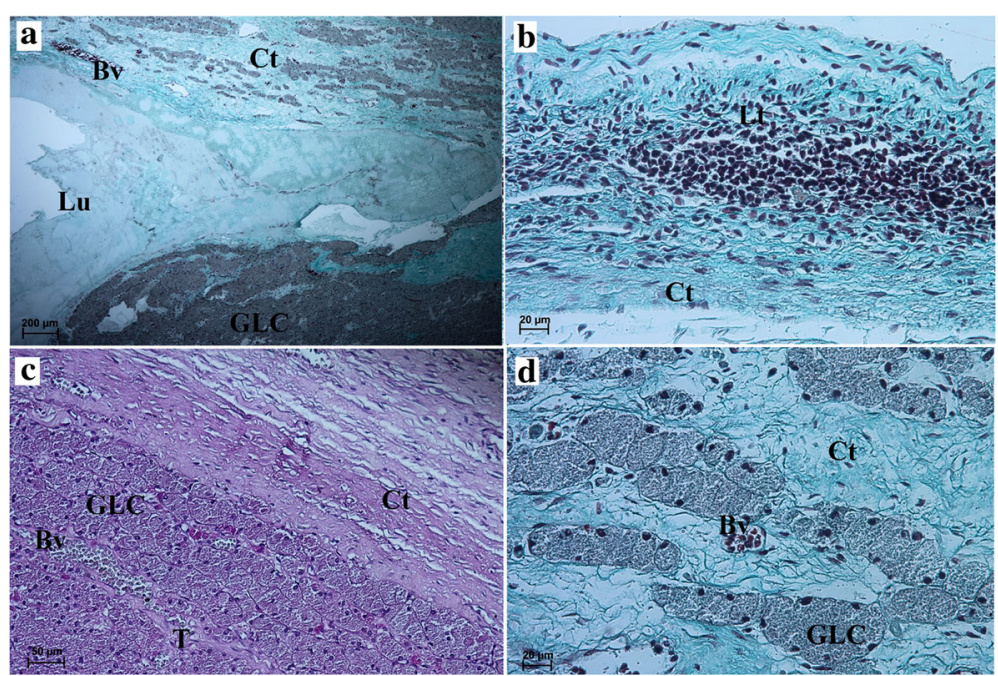

Fig. 4 Microscopic appearance of the ovarian cysts (II type of CL cysts) in the Antillean manatee examined in this study. a Masson-Goldner trichrome staining. Scale bar $=200 \mu \mathrm{m}$. b Masson-Goldner trichrome staining. Scale bar $=20 \mu \mathrm{m}$. c PAS staining. Scale bar $=50 \mu \mathrm{m}$. $\mathbf{d}$ Masson-Goldner trichrome staining. Scale bar $=20$ mm. Abbreviations: Ct: connective tissue; GLC: granular lutein cells; TLC: theca lutein cells; Lu: lumen (follicular cave); Lt: lymphatic tissue; Bv: blood vessels

neoplastic changes, such as a granulosa cell layer and an ovarian adnexal tumour, were recognized [49]. The lesions found within the reproductive organ of the female manatee examined in this study could have induced reproductive problems, but were not the main cause of the animal's death. The ovarian cysts in this case report were not malignant and probably grew slowly. Based on the macroscopic images of the cysts in the manatee, they could be divided into simple ones with a thin and smooth wall, and complex ones with a thick connective tissue wall and various intracystic structures. However, due to the presence of two types of $\mathrm{CL}$ in the manatee ovaries luteal cysts may form from non-ovulating follicles or from $\mathrm{CL}$ after $\mathrm{GF}$

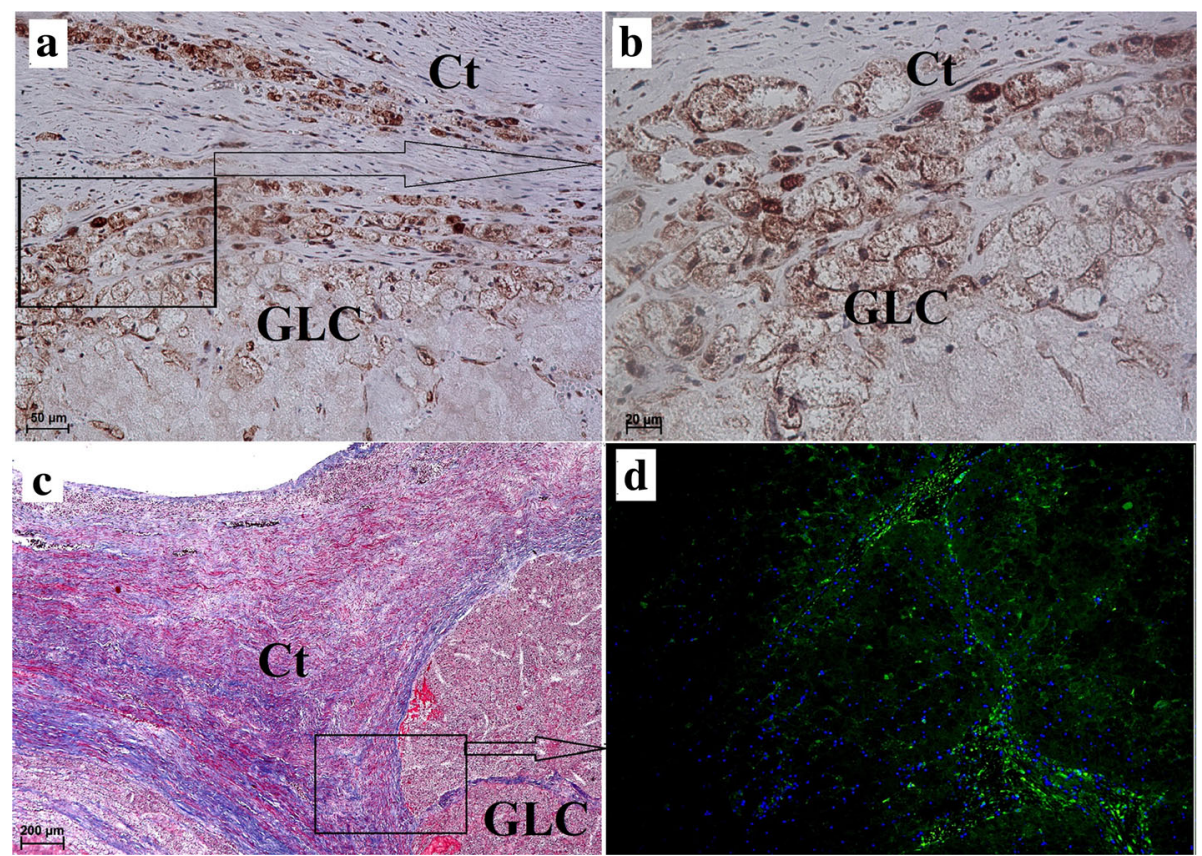

Fig. 5 Vimentin expression in corpus luteum cyst in the Antillean manatee examined in this study. a Vimentin positive expression. Scale bar $=50 \mu m$. b Vimentin. Scale bar $=20 \mu \mathrm{m}$. c Azan staining. Scale bar $=200 \mu \mathrm{m}$. d Immunofluorescence. Vimentin positive expression. Abbreviations: Ct: connective tissue; GLC: granular lutein cells 

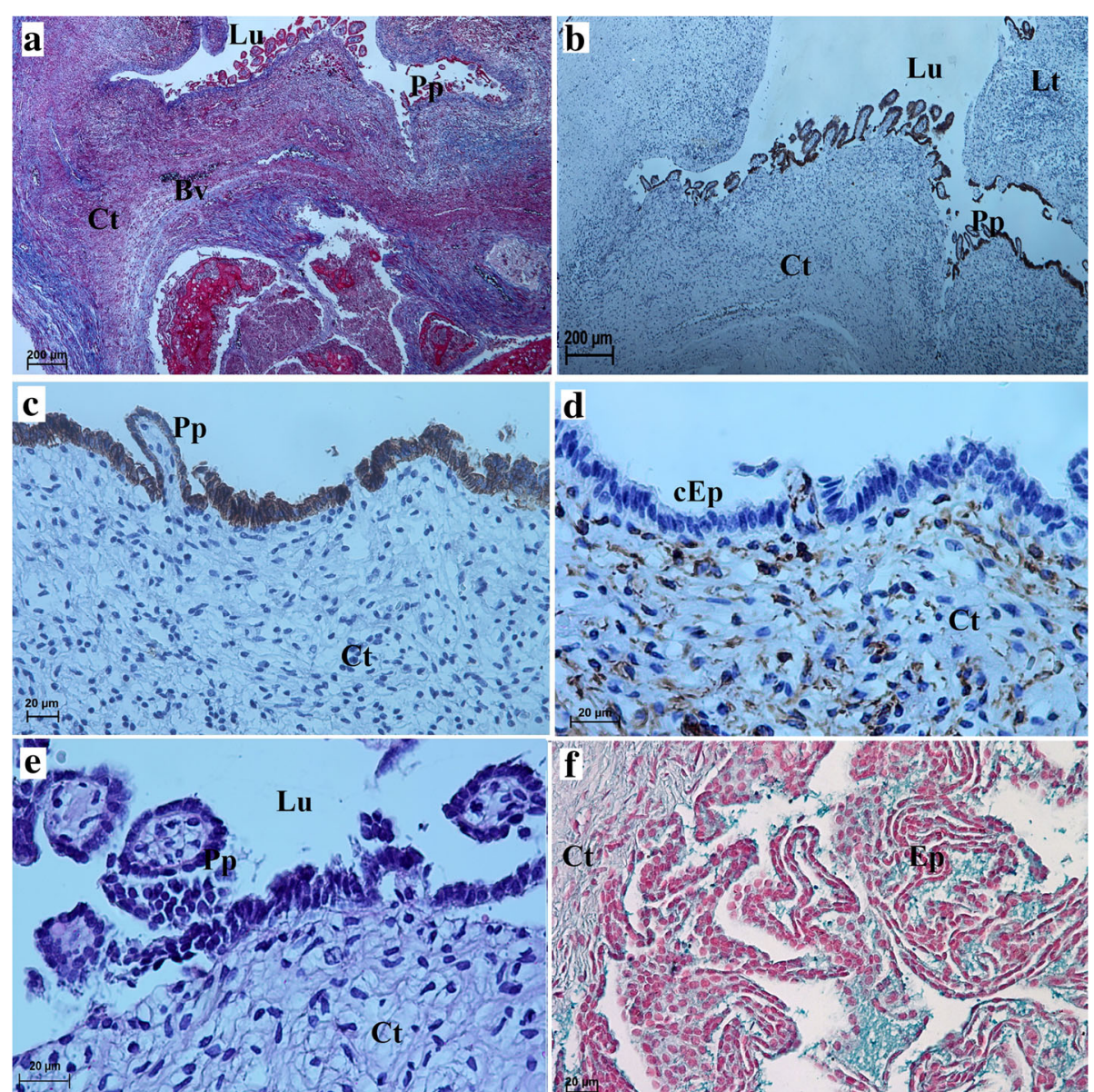

Fig. 6 Microscopic structure of ovarian cysts' stalks in the Antillean manatee examined in this study. a Azan staining. Scale bar = 200 um. b Cytokeratin positive expression. Scale bar $=200 \mu \mathrm{m}$. c Cytokeratin positive reaction. Scale bar $=20 \mu \mathrm{m}$. $\mathbf{d}$ Vimentin positive expression. Scale bar $=20 \mu \mathrm{m}$. e PAS staining. Scale bar $=20 \mu \mathrm{m}$. f AB pH 2.5 staining. Scale bar = $20 \mu \mathrm{m}$. Abbreviations: Ct: connective tissue; Ep: epithelium; CEp: columnar epithelium; Pp: papillary structure; Lu: Iumen; Lt: Iymphatic tissue; Bv: blood vessel

ovulation. Based on the histological assessment of the cysts in the studied Antillean manatee, we found that they were of both CL types. Numerous lymphocyte infiltrates were found in the cystic walls, indicating an inflammatory process. The cysts may have caused infertility in the studied female.

Despite improved diagnostic methods, ovarian masses are frequently detected too late. Ultrasonography is a commonly used non-invasive diagnostic technique in medicine and veterinary medicine. However, this technique has limited use in marine mammals due to the presence of large amounts of adipose tissue surrounding internal organs. Therefore, the detection of ovarian cysts in the described manatee was possible only after necropsy. The pathogenesis of the formation of ovarian cysts is well known in humans [30,31], cattle [32-34], pigs [35], cats [41] and dogs [39, 40]. There is no available data regarding the formation of ovarian cysts in female manatees. To date, the only reported reproductive organ pathologies in the manatee were omphalitis and peritonitis in a young individual [56] and uterine and ovarian neoplasms [49]. Other studies on the reproductive tract in the manatee quantified serum progesterone concentrations in pregnant females [57] and established the morphological features of the mammary glands in the Amazonian manatee [20]. CL cysts have been described in female dolphins [48], and ovarian cysts have been described in the dugong [47]. The ovarian cysts (fluid-filled cysts and adipose cyst) in the dugong were found to be related to age and reproductive activity [47]. Furthermore, a study focusing on Florida manatee females showed that the presence of a reproductive system leiomyoma may depend on the age of the animal [49]. There are several factors apart from age that may significantly affect ovarian lesions in marine mammals.

As in land mammals, the occurrence of ovarian cysts in marine mammals may have a genetic origin. On the other hand, diet, living conditions, stress and age play a crucial 
role in the development of hormonal imbalance and, subsequently, lead to the formation of cysts or reproductive organ neoplasia. In cattle, the presence of ovarian cysts may cause behavioural disorders [28, 33, 34]. It is unclear whether such behavioural disturbances occur in marine mammals. Studies on dolphins indicate that ovarian cysts may also form as a result of high levels of polichlorinated biphenyls and related xenobiotics (PCB), which reduce pituitary secretion of the luteinizing hormone [48]. It is unlikely that PCB had an impact on the female manatee in this study since she had remained in a zoo since birth and was unlikely to be have been exposed to PCB toxins.

Immunohistochemical studies play a key role in the diagnosis of pathological lesions in the ovaries $[58,59,60]$. Therefore, tissue markers were used and showed an expression of cytokeratin and vimentin in the ovarian cyst wall. Both of these markers are usually used in the diagnosis of ovarian tumours. Vimentin is a cytoskeletal protein component of the type III intermediate filament, and is used as a marker of the epithelial-to-mesenchymal transitions [61]. Cytokeratin is a protein found in the intracytoplasmic area of epithelial tissue. In the manatee, cytokeratin showed a low expression within the granulosa layer and strong expression in the ovarian cyst epithelium and in the columnar epithelium of the papillary structures at the ovarian pedicle. In rats, a strong expression of vimentin and cytokeratin within the granulosa cells of the cystic follicles is associated with cytogenesis [61]. During cytogenesis, there is a change in the expression of structural proteins, which leads to changes in function at a cellular level [61]. The results of the expression of vimentin and cytokeratin in ovarian cysts in the Antillean manatee examined in our study are comparable to those of the rat study [61]. It would be useful to study the expression of chosen markers in unchanged manatee ovarian tissue. This would enable a comparison of the expression of those markers in healthy and pathologically changed tissue. To date, the role of TGF $\alpha$ in the regulation of the proliferation of the cells in the granulosa cell tumor have been described [62]. However, there are no reports of the influence of this regulatory factor on the follicular development in the Antillean manatee ovaries. Our study of ovarian cysts in the Antillean manatee forms the basis for further detailed research into the reproductive system in this subspecies of manatee. The remaining reproductive organs were unaltered.

The study carried out on the Antillean manatee showed the presence of cysts typical for land mammals, but the animal had two types of CL cysts of various origin. The use of new research techniques enables better interpretation of results and facilitates treatment trials in marine mammals, more of which are kept in captivity. Due to the growing environmental threats to marine mammals, understanding their disorders and possible treatment options may increase captive populations.

\section{Additional file}

Additional file 1: Methods of analysis entire reproductive tract of the Antillean manatee. (DOC 26 kb)

\section{Abbreviations}

Ac: a actin; Bv: Blood vessel; CA: Corpus albicans; CAt: Corpus atreticus; cEp: Columnar epithelium; CL: Corpus luteum; Ct: Connective tissue; Ec: Endothelial cells; Ep: Epithelium; GF: Graffian follicle; GLC: Granular lutein cells; H\&E: Hematoxylin and eosin staining; IUNC: International Union for Conservation of Nature; KNOW: Leading National Research Center; Lt: Lymphatic tissue; Lu: Lumen; M: Muscle; N: Nucleus; PAS: Periodic acid Schiff staining; PCB: Polichlorinated biphenyls and related xenobiotics; PCOS: Polycystic ovary syndrome; pH 2.5 AB: pH 2.5 alcian blue staining; Pp: Papillary structure; TGF $\beta$ : Transforming growth factors $\beta$;

TGF $\beta_{1}$ : Transforming growth factor $\beta_{1}$; TGF $\beta_{2}$ : Transforming growth factor $\beta_{2}$; TLC: Theca lutein cells

\section{Acknowledgements}

We would like to thank Dr. Lorenzo von Fersen from Tiergarten Nuernberg, Dr. Radosław Ratajszczak - the director of the Wroclaw Zoo, Dr. Mirosław Piasecki, Mr. Krzysztof Zagórny, DVM Wojciech Paszta and Mrs. Ewa Piasecka from the Wroclaw Zoo for providing us with the study material and detailed information about the animal. We would like to thank the Institute of Animal Physiology and Genetics, v.v.i., Academy of Sciences of the Czech Republic, Brno, Czech Republic for the immunohistochemical examinations. We thank Prof. Maciej Janeczek for the revision of the manuscript. We would also like to thank the anonymous reviewers for their constructive comments which helped us improve the manuscript.

Availability of data and materials

All findings associated with the reproductive system of the Antillean manatee female are contained within the manuscript.

\section{Funding}

This study was supported by statutory research and development activity funds assigned to the Faculty of Veterinary Medicine of the Wroclaw University of Environmental and Life Sciences. The translation and publication fee was paid by the Wroclaw Center of Biotechnology, 2014-2018 Leading National Research Center (KNOW) program.

\section{Authors' contributions}

$\mathrm{KGH}$ - conceived the study, collected the material, performed the macroscopic, histological and immunohistochemical examinations, prepared the figures and interpreted the data, wrote the manuscript; JKN- conceived the study, collected the material, wrote the manuscript; SD - interpreted the macroscopic and microscopic results (wrote part of the results) and approved the manuscript. All authors read and approved the final manuscript.

\section{Ethics approval}

This study was compatible with the Polish law since the use of tissues obtained post mortem does not require the approval of the Ethics Committee (Parliament of the Republic of Poland, 2012) (Act of Animal Protection passed on August 21st, 1997 by the Parliament of the Republic of Poland; No. 111/724). The permission to collect the samples from the Wrocław Zoological Garden was obtained from the District Veterinary Officer (Wroclaw).

Consent for publication

Not applicable.

\section{Competing interests}

The authors declare that they have no competing interests.

\section{Publisher's Note}

Springer Nature remains neutral with regard to jurisdictional claims in published maps and institutional affiliations. 


\section{Author details}

'Department of Animal Physiology and Biostructure, Faculty of Veterinary Medicine, Wroclaw University of Environmental and Life Sciences, Kozuchowska 1/3, 51-631 Wroclaw, Poland. ${ }^{2}$ Department of Pathology, Faculty of Veterinary Medicine, Wroclaw University of Environmental and Life Sciences, C.K. Norwida 31, 50-375 Wroclaw, Poland.

Received: 21 July 2016 Accepted: 9 August 2017

Published online: 15 August 2017

\section{References}

1. Domning DP, Hayek LAC. Interspecific and intraspecific morphological variation in manatees (Sirenia: Trichechus). Mar Mamm Sci. 1986;2:87-144.

2. Bossart GD, Meisner RA, Rommel SA, Ghim S, Jenson AB. Pathological features of the Florida manatee cold stress syndrome. Aquat Mamm. 2003; 29:9-17.

3. Wilson DE, Reeder DAM. Trichechidae. In: Mammal Species of the World. A Taxonomic and Geographic Reference. 3rd ed: Johns Hopkins University Press; 2005

4. Laist DW, Taylor C, Reynolds JE. Winter habitat preferences for Florida manatees and vulnerability to cold. PLoS One. 2013;8:e58978.

5. Cichocki W, Ważna A, Cichocki J, Rajska-Jurgiel E, Jasiński A, Bogdanowicz W. Polish nomenclature of animals in the world. Warsaw: Museum and PAN Institute of Zoology; 2015. p. 24.

6. International Union for Conservation of Nature (IUCN) Red List.http://www. iucnredlist.org. Accessed 2 June 2017

7. The Marine Mammal Protection Act of 1972 as amended through 2015. http://www.nmfs.noaa.gov/pr/laws/mmpa/text.htm. Accessed 2 June 2017.

8. Lefebre LM, Marmontel M, Reid JP, Rathbum GB, Domning DP. Distrubuton, status and biogeography, of the West Indian manatee. In: Woods CA, Sergile FE, editors. Biogeography of the West Indies: patterns and perspectives. Boca Raton: CRC Press; 2001. p. 425-74.

9. Castelblanco-Martínez DN, Bermudez-Romero AL, Gomez-Camelo IV, Webar Rosas FC, Trujillo F, Zerda-Ordonez E. Seasonality of habitat use, mortality and reproduction of the vulnerable Antillean manatee Trichechus manatus manatus in the Orinoco River, Colombia: implications for conservation. Oryx. 2009:43:235-42.

10. Castelblanco-Martínez DN, Reis V, Thoisy B. How to detect an elusive aquatic mammal in comlex environments? A study of the endangered Antillean manatee Trichechus manatus manatus in French Guiana. Oryx. 2017: doi:10.1017/S0030605316000922.

11. Ramos EA, Castelblanco-Martínez DN, Landeo-Yauri S, Niño-Torres CA, Magnasco MO, Reiss D. Small drones: a tool to study, monitor, and manage free-ranging Antillean manatees in Belize and Mexico. Sirenews. 2017;20:1-7.

12. Boyd IL, Lockyer C, Marsh H. Reproduction in marine mammals. In: Reynolds III JE, Rommel SA, editors. Biology of marine mammals. Washington DC: Smithsonian Institution Press; 1999. p. 218-86.

13. ILV L. Reproductive endocrinology of the Florida manatee (Trichechus manatus latirostris): estrous cycles, seasonal patterns and behavior. PhD Thesis: University of Florida; 2000. p. 10-4.

14. Marsh H. Terminology of reproductive morphology and physiology. Rep Int Whaling Commision. 1984;3:18-22.

15. Marsh H, O'Shea TJ, Reynolds JE. Ecology and conservation of the Sirenia: dugongs and manatees. Cambridge University Press, Cambridge, United Kingdom. Series: Conservation Biology. 2011;18:536.

16. Pomeroy P. Reproductive cycles of marine mammals. Anim Reprod Sci. 2011;124:184-93.

17. Odell DK, Bossart GD, Lowe MT, Hopkins TD. Reproduction of the West Indian manatee in captivity. In: O'Shea TJ, Ackerman BB, Percival HF, editors. Population biology of the Florida manatee. Washington, DC: U.S. Dept. of the Interior, National Biological Service; 1995. p. 192-3.

18. Marmontel M. The reproductive anatomy of the female manatee Trichechus manatus latirostris (Linnaeus, 1785) based on gross and histologic observations. Ms. Thesis. Florida: University of Miami, Coral Gables; 1988. p. 91

19. Tripp KM. Reproductive and stress analyses in West Indian manatees (Trichechus manatus). PhD Thesis: University of Florida; 2008.

20. Rodrigues FR, Ferreira da Silva FM, Barcellos JF, Lazzarini SM. Reproductive anatomy of the female Amazonian manatee Trichechus inunguis Natterer, 1883 (Mammalia: Sirenia). Anat Rec. 2008;291:557-64.
21. Niswender GD, Juengel JL, Silva PJ, Rollyson MK, McIntush EW. Mechanisms controlling the function and life span of the corpus luteum. Physiol Rev. 2000;80:1-29.

22. May JV, Stephenson LA, Turzcynski CJ, Fong HW, Mau YH, Davis JS. Transforming growth factor beta expression in the porcine ovary: evidence that theca cells are the major secretory source during antral follicle development. Biol Reprod. 1996;54:485-96.

23. Nilsson EE, Doraiswamy V, Skinner MK. Transforming growth factor-beta isoform expression during bovine ovarian antral follicle development. Mol Reprod Dev. 2003;66:237-46.

24. Dumesic DA, Abbott DH. Implications of Polycystic Ovary Syndrome (PCOS) on oocyte development. Semin Reprod Med. 2008;26:53-61.

25. Ebbert $\mathrm{W}$, Bostedt $\mathrm{H}$. Cystic degeneration in porcine ovaries - first communication: Morphology of cystic ovaries, interpretation of the results. Reprod Domest Anim. 1993:28:441-50.

26. Thiryayi SA, Rana DN. The role of cytology in the management of ovarian lesions. In: Pathology of the ovary, Fallopian tube and peritoneum. UK: Wilkinson; 2014. p.169.

27. Madej J, Rotkiewicz T. Pathology of animals. UWM Olsztyn. 2011;

28. Jeengar K, Chaudhary V, Kumar A, Raiya S, Gaur M, Purohit NA. Ovarian cysts in dairy cows: old and new concepts for definition, diagnosis and therapy. Anim Reprod. 2014;11:63-73.

29. Knauf Y, Bostedt H, Failing K, Knauf S, Wehrend A. Gross pathology and endocrinology of ovarian cysts in bitches. Reprod Domest Anim. 2014;49: 463-8.

30. Barbuscia M, De Luca M, llaqua A, Cingari E, Lemma G, Querci A, Lentini M, Gorgone S. Etiopathogenetic and clinical considerations of corpus luteum cysts. G Chir. 2010;3:103-7.

31. Choi NJ, Rha SE, Jung SE, Choi BG, Oh SN, Byun JY, Kim RM. Ruptured endometrial cysts as a rare cause of acute pelvic pain: can we differentiate them from ruptured corpus luteal cysts on CT scan? J Comput Assist Tomogr. 2011;35:454-8.

32. Peter AT, Levine $H$, Drost M, Bergfeld DR. Compilation of classical and contemporary terminology used to describe morphological aspects of ovarian dynamics in cattle. Theriogen. 2009;71:1343-57.

33. Rosenberg LM. Cystic ovaries in Dairy cattle. Dairy Science Department California Polytechnic State University, San Luis Obispo; 2010. p. 1-34.

34. Navanukraw C, Khanthusaeng V, Kraisoon A, Suwannarit D, Jarassaeng C, Aiumlami S. Synchronization of ovulation with human chorionic gonadotropin in lactating dairy cows with ovarian cysts during heat stress. Trop Anim Health Prod. 2015;47:945-51.

35. Cech S, Dolzel R. Treatment of ovarian cysts in sows- a field trial. Vet Med. 2007:52:413-8

36. McCue P. Review of ovarian abnormalities in the mare. Proceedings of the Annual Convention of the AAEP. 1998:44:125-33.

37. Medan MS, Watanabe G, Sasaki K, Taya K. Transrectal ultrasonic diagnosis of ovarian follicular cysts in goats and treatment with GnRH. Domest Anim Endocrinol. 2004;27:115-24.

38. Christman SA, Bailey MT, Head WA, Wheaton JE. Induction of ovarian cystic follicles in sheep. Domest Anim Endocrinol. 2000;19:133-46.

39. Greenlee PG, Patnaik AK. Canine ovarian tumors of germ cell origin. Vet Pathol. 1985;22:117-22.

40. MacLachlan NJ, Kennedy PC. Tumors of the genital systems. In: Meuten DJ, editor. Tumors in Domestic Animals. lowa: Iowa State Press; 2002. p. 547-73.

41. Sapierzyński R. Tumors of urogenital system in dogs and cats. III Part. Ovarian, uterine and vaginal tumors. Życie Wet. 2007;82:35-8.

42. Nielsen TD, Holt S, Ruelokke ML, McEvoy FJ. Ovarian cysts in quinea pigs: Influence of age and reproductive status on prevalence and size. J Small Anim Pract. 2003;44:257-60.

43. Pilny A. Ovarian cystic disease in guinea pigs. Vet Clin North Am Exot Anim Pract. 2014;17:69-75

44. Van Houten EL, Visser JA. Mouse models to study polycystic ovary syndrome: a possible link between metabolism and ovarian function? Reprod Biol. 2014;14:32-43.

45. Van der Horst PH, van der Zee M, Heijmans-Antonissen JY, FJ DM, Lydon JP, van Deurzen $\mathrm{CH}$, Ewing PC, Burger CW, Blok $L$. A mouse model for endometrioid ovarian cancer arising from the distal oviduct. Int J Cancer. 2014:135:1028-37.

46. He H, Teng H, Zhou T, Guo Y, Wang G, Lin M, Sun Y, Si W, Zhou Z, Guo X, Huo R. Unravelling the proteome of adult rhesus monkey ovaries. Mol Bio Syst. 2014;10:653-62. 
47. Marsh H, Heinsohn GE, Channels PW. Changes in the ovaries and uterus of the dugong, Dugong dugon (Sirenia: Dugongidae), with age and reproductive activity. Aust J Zool. 1984;32:743-66.

48. Munson L, Calzada N, Kennedy S, Sorensen TB. Luteinized ovarian cysts in Mediterranean striped dolphins. J Wildl Dis. 1998;34:656-60.

49. Smith LN, Rotstein DS, Ball RL, Gerlach TJ, Kinsel M, Rodriguez M, de Wit M. Reproductive neoplasms in wild and long-term captive female Florida manatees (Trichechus manatus latirostris). J Zoo Wildl Med. 2015;46:895-903.

50. Mawdesley-Thomas LE. An ovarian tumour in a Southern Elephant seal (Mirounga leonina). Vet Pathol. 1971a;8:9-15.

51. Mawdesley-Thomas LE, Bonnerw WN, et al. J Pathol. 1971b:103, 205-8.

52. Backlin BM, Eriksson L, Olovsson M. Histology of uterine leiomyoma and occurrence in relation to reproductive activity in the Baltic gray seal (Halichoerus grypus). Vet Pathol. 2003:40:175-80.

53. Olsen J, Komtebedde J, Lackner A, Madewell BR. Cytoreductive treatment of ovarian carcinoma in a dog. J Vet Intern Med. 1994;8:133-4.

54. Kamel A. Massive ovarian mucinous cystadenoma: a case report. Reprod Biol Endocrinol. 2010;8:24.

55. Jergens AE, Knapp DW, Shaw DP. Ovarian teratoma in a bitch. J Am Vet Med Assoc. 1987;191:81-3.

56. Walsh MT, Bossart GD, Young WG, Rose PM. Omphalitis and peritonitis in a young West Indian manatee (Trichechus manatus). J Wild Dis. 1987;23:702-4.

57. Tripp KM, Verstegen JP, Deutsch CJ, Bonde RK, Rodriguez M, Morales B, Schmitt DL, Harr KE. Validation of a serum immunoassay to measure progesterone and diagnose pregnancy in the West Indian manatee (Trichechus manatus). Theriogenol. 2008:70:1030-40.

58. Akihara Y, Shimoyama Y, Kawasako K, Komine M, Hirayama K, Kagawa Y, Omachi T, Matsuda K, Okamoto M, Kadosawa T, Taniyama H. Immunohistochemical evaluation of canine ovarian cysts. J Vet Med Sci. 2007:69:1033-7.

59. Riccardi E, Greco V, Verganti S, Finazzi M. Immunohistochemical diagnosis of canine ovarian epithelial and granulosa cell tumors. J Vet Diagn Investig. 2007:19:431-5.

60. Desouki MM, Kallsa SJ, Khabele D, Crispens MA, Hameed O, Fadare O. Differential vimentin expression in ovarian and uterine corpus endometrioid adenocarcinomas: diagnostic utility in distinguishing double primaries from metastatic tumors. Int J Gynecol Pathol. 2014;33:274-81.

61. Salvetti NR, Gimeno EJ, Lorente JA, Ortega HH. Expression of cytoskeletal proteins in the follicular wall of induced ovarian cysts. Cells Tissues Organs. 2004;178:117-25.

62. Wang C, Xiangmin L, Jiang C, Cordes CM, Fu L, Lele SM, Davis JS. Transforming growth factor alpha (TGFa) regulates granulosa cell tumor (GCT) cell proliferation and migration through activation of multiple pathways. PLoS One. 2012;7:448299.

\section{Submit your next manuscript to BioMed Central and we will help you at every step:}

- We accept pre-submission inquiries

- Our selector tool helps you to find the most relevant journal

- We provide round the clock customer support

- Convenient online submission

- Thorough peer review

- Inclusion in PubMed and all major indexing services

- Maximum visibility for your research

Submit your manuscript at www.biomedcentral.com/submit

) Biomed Central 